\title{
Genotype $x$ environment interaction and stability analysis for yield and yield components in ten flax genotypes.
}

\author{
Abd El-Haleem, R.A.; Maysa S. Abd Al-Sadek and H.M.H.Abo-Kaied \\ Fiber Crops Res. Dep., Field Crops Res .Inst. A.R.C., Giza \\ Corresponding author: abokaiedfiber@gmail.com
}

\begin{abstract}
Ten flax genotypes $(G)$ were evaluated over six environments (E) "combination of three years $(2013 / 14$, 2014/15 and 2015/16) and two locations (Giza Exp. Sta., Giza Governorate and Ismaelia Exp. Sta., Ismaelia Governorate) in Egypt to determine genotype X environment (GE) interaction and stability.

Mean squares of genotypes and Environments (E) were highly significant for all studied characters, indicating that the genotypes differ in their genetic potential as well as variability among the environments studied. Also, GxE interaction was significant for all characters except, straw weight per plant, 1000-seed weight and no of seeds per capsule. This result indicated that genotypes had considerable different responses to environmental conditions. The significant variance due to residual (pooled deviation) for all characters indicated that genotypes differed with respect to their stability suggesting that prediction would be difficult, which means that mean performance alone (mean yield) would not be appropriate. Estimates of variance components, phenotypic (PCV) and genotypic (GCV) coefficients of variability and broad sense heritability $(\mathrm{H})$ indicated the possibility of using plant height as selection index for improving straw weight per plant and both of 1000-seed weight and no. of capsules per plant in selection index for improving seed weight per plant. Based on estimates of mean performance $(\overline{\mathrm{x}})$ and four stability parameters (regression coefficient (b), deviation from regression $\left(S^{2} d\right)$, coefficient of determination $\left(r^{2}\right)$ and the ecovalence stability index (w)), it could be concluded that L.541-D/5 could be considered as ideal genotypes for all studied characters as well as L.541-C/8 could be considered as ideal genotypes for the three traits which related of seed (seed yield per fed, oil yield per fed and oil percentage). Thus, they are recommended to be released as stable high-yielding cultivars and/or to be incorporated in the breeding stocks in any breeding program aiming to produce stable genotypes for the above-mentioned characters. Phenotypic correlation coefficients among straw weight and other components indicated the possibility of selecting genotypes characterized by high straw yielding ability and in the same time high seed yield potentialities. However, seed yield per plant was significant positively correlated with both no. of capsules per plant and 1000-seed weight. Also, no. of capsules per plant exhibited highly significant positive correlation with 1000-seed weight. These results indicate the possibility of using plant height as a selection index for improving straw weight per plant and both of 1000-seed weight and no. of capsules as selection indices for improving seed weight per plant.
\end{abstract}

Key words: Flax, genotype x environment interactions, correlation, stability.

\section{Introduction}

Flax (Linum usitatissimum L.) has been grown since the beginnings of civilization, and people all over the world have celebrated its usefulness throughout the ages, both as a food and in the manufacture of clothing. In Egypt, flax is cultivated for two purposes, seeds and fibers.

Stable performance of varieties under different environments with regard to the economic characters like straw yield and/or seed yield is of major significance in any breeding program. In order to initiate the development of stable genotypes, information on various stability aspects and their mode of transmission would be very essential. The yield level, yield stability and genetic variance of the base populations would thus determine the success of any selection programs (Kofoid et al., 1978). The new released cultivars must be contain desired traits, such as high yield, tolerance or resistance to biotic and abiotic stresses, and stability to target environments.
In consistent genotypic responses to environmental factors such as, soil moisture, soil type, or fertility level from location to location and year-to-year is a function of genotype $x$ environment (GE) interaction. GE interaction encountered in yield traits are a challenge to plant breeders. The GE interaction has been shown to reduce progress from selection (Comstock and Moll, 1963). In addition to high mean yield, information on a cultivar's stability performance across environments would enable breeders to select more consistent performing cultivars. Many investigators studied GE interactions and stability of flax genotypes under different environments (Abo El-Zahab et al., 1994; Abo ElZahab and Abo-Kaied, 2000 and Abo-Kaied et al., 2015).

The objective of this study was to determine genotype $\mathrm{X}$ environment (GE) interaction and stability for ten flax genotypes as well as effect of different environments on yield and yield components to understand its adaptation to varying environments. 


\section{Materials and Methods}

Ten flax genotypes included Sakha 3 as commercial flax variety, introduction Belinka and eight local lines (L.) were used in this study. The classification and pedigree of the genotypes are presented in Table (1).

Table 1. Pedigree of the ten flax genotypes and their classification (fiber type, F; dual type, D; oil type, O).

\begin{tabular}{llll}
\hline No. & Genotype & Pedigree & Type \\
\hline 1 & Sakha 3 & I. Belinka x I. 2569 & $\mathrm{F}$ \\
2 & Belinka & Introduction from Holand & $\mathrm{F}$ \\
3 & L.541-C/6 & Giza $8 \times$ S.2419/1 & $\mathrm{D}$ \\
4 & L.541-C/9 & Do & $\mathrm{D}$ \\
5 & L.870/3/6 & Elona XS.2476/1 & $\mathrm{D}$ \\
6 & L.883/7/4 & Belinka x S.2419/1/3 & $\mathrm{D}$ \\
7 & L.541-C/8 & Giza $8 \times$ S.2419/1 & $\mathrm{D}$ \\
8 & L.541-D/5 & S.2419/1 x S.148/6/1 & $\mathrm{D}$ \\
9 & L.541-D/9 & Do & $\mathrm{D}$ \\
10 & L.402/3/3/5 & Giza $5 \times$ I. 235 (U.S.A.) & $\mathrm{O}$ \\
\hline
\end{tabular}

The genotypes were evaluated in three successive seasons (2013/14, 2014/15 and 2015/16) at two locations viz: Giza Exp. Sta., Giza Governorate \{old land (clay loamy with organic matter of $2.05 \%$, available nitrogen $23.45 \mathrm{ppm}$ and $\mathrm{pH}$ value of 7.75)\} and Ismaelia Exp. Sta., Ismaelia Governorate \{newly reclaimed land (Sandy clay loamy with organic matter of $0.65 \%$, available nitrogen $7.44 \mathrm{ppm}$ and $\mathrm{pH}$ value of 8.61)\}. Six experiments (three seasons $x$ two locations) were carried out. Sowing was done during the first week of November in all locations and seasons, the plot size was $2 \times 3 \mathrm{~m}$ consisting of 10 rows, $20 \mathrm{~cm}$ apart and $3 \mathrm{~m}$ long. Plant density of 1500 seeds/m2 was used, a randomized complete block design with three replications was applied at all experiments. Recommended cultural practices were maintained as recommended at optimum levels.

At harvest, data on ten randomly guarded plants in each plot were recorded to determine the averages of the individual plant traits. Straw, seed and fiber yields/fad $\left(4200 \mathrm{~m}^{2}\right)$ was calculated on plot mean basis. Oil percentage was determined as an average of two random seed samples/plot using a Soxhlet apparatus (A.O.A.C. Society, 1995). The following characters were recorded:

I) Straw yield and its components: (1) Straw yield/fad (ton); (2) Straw weight/plant (g); (3) Plant height $(\mathrm{cm})$ and (4) Technical stem length $(\mathrm{cm})$.

II) Seed yield and its components: (1) Seed yield/fad (Kg); (2) Seed weight/plant (g); (3) No. of capsules/plant; (4) 1000-seed weight (g) and (5) No. of seeds/capsule.

III) Fiber and oil yields/fad and some technological characters: (1) Fiber yield/fad (Kg); (2) Oil yield/fad $(\mathrm{Kg})$; (3) Fiber percentage (\%) and (5) Oil percentage $(\%)$.

\section{Statistical analysis:}

Analysis of variance was made for each environment separately. Bartlett' test of homogeneity was used before combined analysis. The estimates of the variance components were calculated by using the expected mean squares (Johnson et al. 1959). Phenotypic correlation coefficients were calculated according to the formula suggested by Al-Jibouri et al., (1958).

\section{Stability measurements:}

Genotype stability was detected via determining four stability parameters. The first parameter is the linear regression coefficient (b value) and the second stability parameter was the mean square of deviation from regression for each entry $\left(\mathrm{S}^{2} \mathrm{~d}\right.$ value) as described by Eberhart and Russel (1966). The third stability parameter was coefficient of determination $\left(r^{2}\right)$ as outlined by Pinthus (1973), which was computed from the linear regression analysis. Finally, the fourth parameter was the ecovalence $\left(\mathrm{W}_{\mathrm{i}}\right)$, the contribution of each variety to the genotype $\mathrm{x}$ environment interaction. It was calculated for each genotype according to method of Wricke (1962).

\section{Results and Discussion}

\section{Analysis of variance:}

Mean square for straw and seed yields and their components as well as some technological characters of ten flax genotypes based on data of the six environments ( 3 years and 2 locations) are presented in Table (2). Genotype mean square was highly significant for all characters, indicating that the genotypes differed in their genetic performance for these traits. This result coupled with the large values of phenotypic coefficient of variability for all characters (Table 3) support the evident that great variability exists among the tested genotypes. Such variability among different flax genotypes in straw and seed yields and their related characters was also reported by Abo El-Zahab et al. (1994); Abo El-Zahab and Abo-Kaied (2000) and Abo-Kaied et al. (2015). Environments (E) differed highly significantly for all traits, indicating a wide range of variation among the environments studied. Also, GxE interaction was significant for all characters except straw yield/plant, 
1000-seed weight and no. of seeds/capsule. This result indicated that genotypes had considerable different responses to environmental conditions.

The ratio between the two variances $(G$ and $\mathrm{GxE}$ ) was greater for all characters studied indicating that improvement of these characters could be achieved by selection. The variances due to E (linear) were statistically significant for all traits except fiber percentage and no. of seeds/capsule. Also, the variances due to heterogeneity ( $\mathrm{GxE}$ linear) were highly significant for all characters except straw yield/fed, fiber yield/fed and no. of seeds/capsule, suggesting that linear components of genotype environment was present. The significant variance due to residual (pooled deviation) for all characters indicated that genotypes differed with respect to their stability suggesting that prediction would be difficult, which means that mean performance alone (mean yield) would not be appropriate. In such situation, methods that combine yield and stability of performance are useful (Bachireddy et al., 1992).

\section{Variance components:}

Estimates of variance components among ten flax genotypes grown at six environments for straw, seed weight/plant and their components as well as some technological characters are shown in Table 3. Interaction components variances $\left(\sigma^{2}\right.$ ge $)$ were less than the genotypic variance $\left(\sigma^{2} g\right)$ for all characters except each of straw weight/plant, no. of capsules/plant. This means that genotypes differ in their genetic potential for these traits. This was reflected in high heritability and low discrepancy between PCV and GCV values for plant height ( $\mathrm{H}$ $98.10 \%, \mathrm{PCV}=3.20 \%, \mathrm{GCV}=3.17 \%)$, technical stem length $(\mathrm{H}=90.30, \mathrm{PCV}=2.95 \%, \mathrm{GCV}=$ $2.80 \%)$, fiber percentage $(\mathrm{H}=96.97 \%, \mathrm{PCV}=1.69 \%$, $\mathrm{GCV}=1.69 \%)$, no. of seeds $/$ capsule $(\mathrm{H}=99.45 \%$, $\mathrm{PCV}=3.73 \%, \mathrm{GCV}=3.72 \%), 1000$-seed weight $(\mathrm{H}=$ $99.64 \%, \mathrm{PCV}=5.78 \%, \mathrm{GCV} 5.77 \%)$, and oil percentage $(\mathrm{H}=97.33 \%, \mathrm{PCV}=1.78 \%, \mathrm{GCV}=$ $1.84 \%)$. These results indicating the possibility of using both of plant height and technical stem length as selection indices for improving straw weight/plant and both of no. of seeds/capsule and 1000-seed weight as selection indices for improving seed weight per plant. In contrast, Interaction component of variance $\left(\sigma^{2}\right.$ ge) was more than the genotypic variance $\left(\sigma^{2} g\right)$ for both straw weight/plant and no. of capsules/plant. This was reflected in mediate heritability values for straw weight/plant $(\mathrm{H} 85.58 \%)$ and no. of capsules/plant $(\mathrm{H}$ $68.92 \%)$. This result clearly indicates that variation among flax genotypes in the two previous traits are mainly due to environmental variation plus the GE interaction ones. These results are in harmony with those reported by Abo El-Zahab et al., (1994), Mourad et al., (2003) and Abo-Kaied et al.,(2015).

\section{Mean performance:}

The significant differences among genotypes in Table (4) show that three lines, 541-C/8, 541-D/5 and 541-D/9 recorded high mean performance than the other genotypes in straw weight/plant and plant height. L.541-D/5 flowed by L.541-C/9 and L.541$\mathrm{C} / 6$ exceeded significantly the other genotypes in technical stem length. L.541-C/8 flowed by L.541-D/5 and L.541-C/9 surpassed the other genotypes for seed weight and no. of capsules/plant. For 1000-seed weight, L.541-C/8 flowed by L.541-C/9 and L.541$\mathrm{C} / 6$ recorded high mean performance than the other genotypes. On the other hand, introduction Belinka recorded low mean value for 1000 -seed weight.

In general, the line 541-D/5 proved to be superior in straw weight and its two important components (plant height and technical length) in addition seed weight/plant and technical stem length. Similar trend was recorded by L.541-C/9 for seed weight and its most components (no. of capsules/plant and 1000seed weight). Therefore, these lines (541-D/5 for straw weight as well as 541-C/9 for seed weight) may be incorporated as breeding stocks in flax breeding program aiming to improve these important mentioned characters.

\section{Stability measurements:}

Mean squares due to genotype $\mathrm{x}$ environment interaction plus environment linear effects were significant for all characters, i.e. straw, seed, fiber and oil yields per fad as well as some technological traits, i.e. fiber percentage and oil percentage (Table 2). The significant mean squares due to environment (linear) indicated differences between environments. The variances due to GxE (linear) were statistically significant for all the above-mentioned characters suggesting that linear component of genotype $\mathrm{x}$ environment was present. There were also differences among the regression coefficients for the genotypes. The significant variances due to pooled deviation for all the above-mentioned characters, indicated that genotypes differed with respect to their stability and suggesting that the prediction of stability would be difficult.

Estimates of mean performance $(\overline{\mathrm{x}})$, regression coefficient (b), deviation from regression $\left(\mathrm{S}^{2} \mathrm{~d}\right)$, coefficient of determination $\left(\mathrm{r}^{2}\right)$ and the ecovalence stability index (w) for straw, seed, fiber and oil yields per fad as well as some technological characters (fiber percentage and oil percentage) are presented in Table (5). The ideal genotype as proposed by Eberhart and Russell (1966) would have a high mean performance $(\overline{\mathrm{x}})$ over a range of environments, a regression coefficient (b) not significantly different from one and deviation mean square from regression $\left(S^{2} d\right)$ not significantly different from zero. 
Table 2. Combined ANOVA for straw, seed yields and their components as well as some technological characters of ten flax genotypes based on data of six environments (2 locations x 3 years).

\begin{tabular}{|c|c|c|c|c|c|c|c|c|c|c|c|c|c|c|c|}
\hline S.O.V. & d.f & 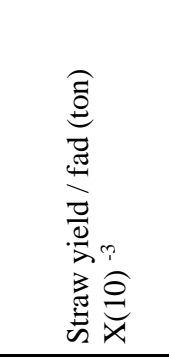 & 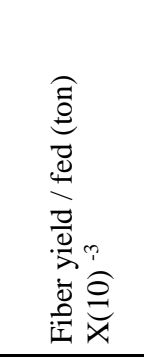 & 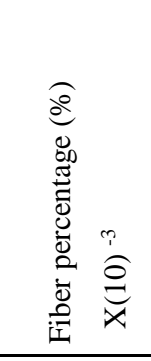 & 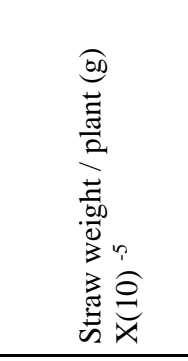 & 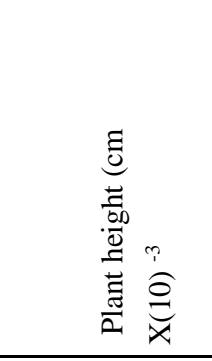 & 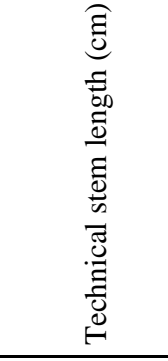 & 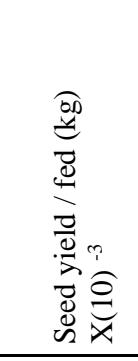 & 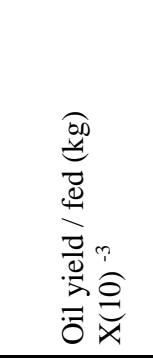 & 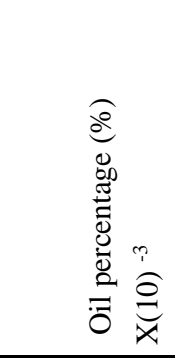 & 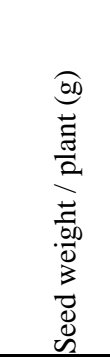 & 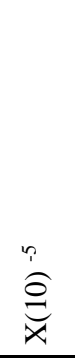 & 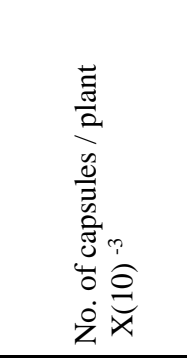 & 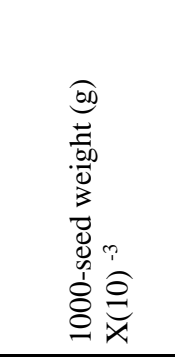 & 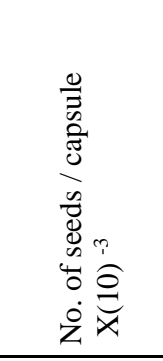 \\
\hline Environment (E) & 5 & $5819.155^{* *}$ & $146.019 * *$ & *2747.733*: & $* 108545.617 *$ & $* 1567923.027 * *$ & *2492.978** & $257.043 *$ & $* 40.317 * *$ & $3978.412 * *$ & 16723. & $612 * *$ & $* 35127.378 * *$ & $717.449 * *$ & $183.187 * *$ \\
\hline Genotype (G) & 9 & $691.516^{* *}$ & $24.649 * *$ & $3780.007 *$ & $* 17396.052 * *$ & $572297.589 * *$ & $271.694 * *$ & $114.237 *$ & $* 24.512 * *$ & $29965.628 *$ & $* 3527.3$ & $80 * *$ & $6016.506 * *$ & $14704.937 * *$ & *3983.617** \\
\hline$(\mathrm{G} \times \mathrm{E})$ & 45 & $193.510 * *$ & $5.148^{* *}$ & $69.515 * *$ & 1221.218 & $5399.394 * *$ & $13.272 * *$ & $2.902 * *$ & $0.561 * *$ & $435.838^{* *}$ & 498.63 & $8 * *$ & $1041.714 * *$ & 2.155 & 8.535 \\
\hline $\mathrm{E}+(\mathrm{G} \times \mathrm{E})$ & 50 & $756.075 * *$ & $19.235 * *$ & $337.337 * *$ & $11953.658 * *$ & $161651.757 * *$ & $261.243 * *$ & $28.316^{* *}$ & $4.537 * *$ & $790.096 * *$ & 2121.1 & $35 * *$ & $4450.280 * *$ & $73.684 * *$ & $26.000 * *$ \\
\hline E (linear) & 1 & $29095.774 *$ & *730.096** & *13738.664 & $542728.084 *$ & $* 7839615.134 * *$ & *12464.888*: & $* 1285.215$ & $201.587 * *$ & * $19892.060 *$ & $* 83618$. & $058 * *$ & $* 175636.890 * *$ & *3587.246* & 915.936 \\
\hline G x E (linear) & 9 & 80.476 & 3.531 & $140.212 * *$ & $6085.768 * *$ & $23913.281 * *$ & $39.647 * *$ & $7.413^{* *}$ & $1.615^{* *}$ & $642.647 * *$ & 1160.76 & $67 * *$ & $2227.238 * *$ & $10.774 * *$ & 2.704 \\
\hline pooled deviation & 40 & $199.592 * *$ & $4.997 * *$ & $46.656 * *$ & $4.572 * *$ & $693.830 * *$ & $6.011^{* *}$ & $1.597 * *$ & $0.268 * *$ & $345.722 * *$ & 299.795 & $5 * *$ & $670.800 * *$ & 0.000 & $8.993 * *$ \\
\hline pooled error & 108 & 11.097 & 0.273 & 2.251 & 0.185 & 4.085 & 0.248 & 0.149 & 0.024 & 7.390 & 0.044 & & 1.069 & 0.147 & 0.721 \\
\hline
\end{tabular}
*, **: Significant at 0.05 and 0.01 probability levels, respectively. 
Table 3. Variance components estimates from combined ANOVA, phenotypic (PCV) and genotypic (GCV) coefficients of variability and broad sense heritability $(\mathrm{H})$ for straw, seed weight per plant and their components of ten flax genotypes grown at six environments. Straw weight and its components Seed weight and its components

\begin{tabular}{|c|c|c|c|c|c|c|c|c|c|}
\hline $\begin{array}{l}\text { Variance } \\
\text { components }\end{array}$ & 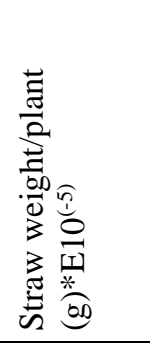 & 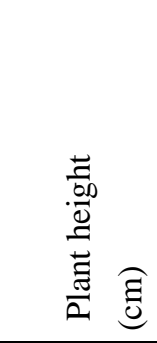 & 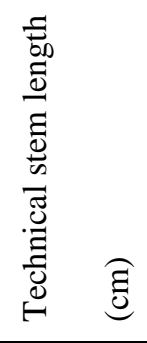 & 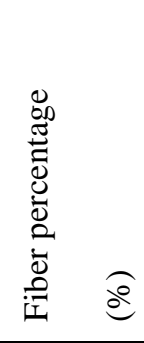 & 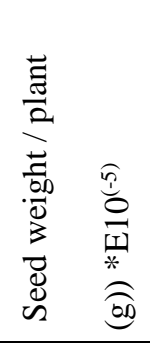 & 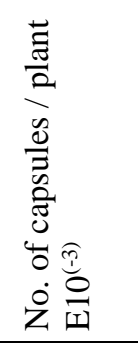 & 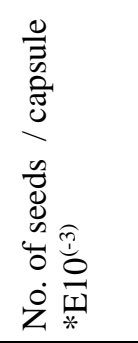 & 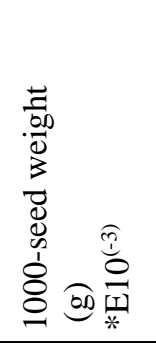 & 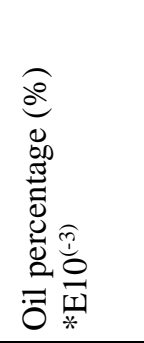 \\
\hline$\sigma_{\mathrm{ph}}^{2}$ & $32.215^{* *}$ & $10.598 * *$ & $5.031 * *$ & $0.070 * *$ & $6.541 * *$ & $0.111 * *$ & $7.377 * *$ & $27.231 * *$ & $55.492 * *$ \\
\hline$\sigma_{\mathrm{g}}^{2}$ & $27.568^{* *}$ & $10.397 * *$ & $4.544 * *$ & $0.068 * *$ & $5.787 * *$ & $0.077^{* *} *$ & $7.337 * *$ & $27.134 * *$ & $54.011 * *$ \\
\hline$\sigma_{\mathrm{ge}}^{2}$ & 27.874 & $1.204 * *$ & $2.844 * *$ & $0.012 * *$ & $4.519 * *$ & $0.207 * *$ & $0.219 * *$ & 0.576 & $8.641 * *$ \\
\hline$\sigma_{\mathrm{e}}^{2}$ & 0.018 & 0.004 & 0.248 & 0.002 & 0.002 & 0.001 & 0.072 & 0.015 & 0.739 \\
\hline PCV\% & 5.690 & 3.20 & 2.95 & 1.69 & 8.215 & 6.98 & 3.73 & 5.78 & 1.87 \\
\hline GCV\% & 5.263 & 3.17 & 2.80 & 1.66 & 7.727 & 5.80 & 3.72 & 5.77 & 1.84 \\
\hline $\mathrm{H} \%$ & 85.576 & 98.10 & 90.30 & 96.97 & 88.483 & 68.92 & 99.45 & 99.64 & 97.33 \\
\hline
\end{tabular}

$*, * *:$ Significant at 0.05 and 0.01 probability levels, respectively.

$\sigma_{\mathrm{ph},}^{2} \sigma_{\mathrm{g},}^{2} \sigma_{\mathrm{ge}}^{2}, \sigma_{\mathrm{e}}^{2}$ are the variance attributed to phenotype, genotypes, genotypes x environment, environment respectively. 
Table 4. Mean values for straw and seed weight per plant and their components of ten flax genotypes grown at six environments.

Straw weight and its components Seed weight and its components

\begin{tabular}{|c|c|c|c|c|c|c|c|}
\hline Genotype & 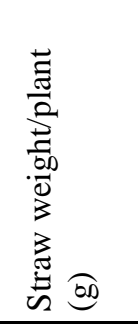 & 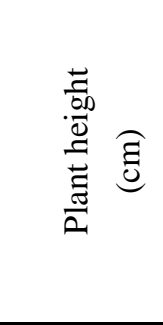 & 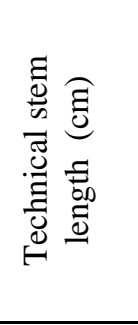 & 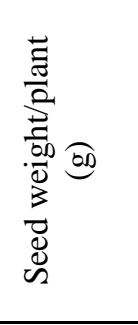 & 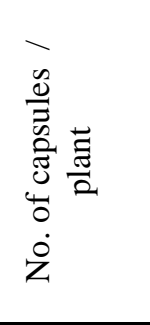 & $\begin{array}{l}\vec{Z} \\
.00 \\
0 \\
3 \\
0 \\
0 \\
0 \\
0 \\
0 \\
8 \\
8 \\
0\end{array}$ & 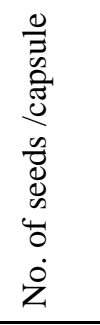 \\
\hline 1-Sakha 1 & $0.925 \mathrm{e}$ & $95.8 \mathrm{~h}$ & $69.21 \mathrm{f}$ & $0.288 \mathrm{f}$ & 4.427 ef & $8.81 \mathrm{~h}$ & $7.32 \mathrm{~d}$ \\
\hline 2-Belinka & $0.757 \mathrm{e}$ & $97.8 \mathrm{~g}$ & $79.63 \mathrm{c}$ & $0.173 \mathrm{i}$ & $3.686 \mathrm{~h}$ & $5.18 \mathrm{j}$ & $9.03 \mathrm{a}$ \\
\hline $3-541 / \mathrm{C} / 6$ & $1.061 \mathrm{~d}$ & $105.2 \mathrm{e}$ & $80.10 \mathrm{c}$ & $0.330 \mathrm{~d}$ & $4.807 \mathrm{c}$ & $10.03 \mathrm{c}$ & $6.83 \mathrm{f}$ \\
\hline $4-541 / \mathrm{C} / 9$ & $1.075 \mathrm{~d}$ & $107.3 \mathrm{c}$ & $82.22 \mathrm{~b}$ & $0.375 \mathrm{c}$ & $5.505 \mathrm{i}$ & $10.14 \mathrm{~b}$ & $6.71 \mathrm{~g}$ \\
\hline $5-870 / 3 / 6$ & $0.859 \mathrm{f}$ & $100.2 \mathrm{f}$ & $78.10 \mathrm{~d}$ & $0.235 \mathrm{~h}$ & $3.348 \mathrm{~g}$ & $8.86 \mathrm{j}$ & $7.88 \mathrm{c}$ \\
\hline $6-883 / 7 / 4$ & $0.877 \mathrm{f}$ & $86.9 \mathrm{j}$ & $66.31 \mathrm{~g}$ & $0.259 \mathrm{~g}$ & $4.213 \mathrm{~b}$ & $7.70 \mathrm{i}$ & $7.98 \mathrm{~b}$ \\
\hline $7-541 / \mathrm{C} / 8$ & $1.114 \mathrm{c}$ & $108.0 \mathrm{c}$ & $78.71 \mathrm{~d}$ & $0.416 \mathrm{a}$ & $6.204 \mathrm{a}$ & $10.24 \mathrm{a}$ & $6.50 \mathrm{~h}$ \\
\hline $8-541 / \mathrm{D} / 5$ & $1.208 \mathrm{~b}$ & $114.6 \mathrm{a}$ & $86.02 \mathrm{a}$ & $0.407 \mathrm{~b}$ & $6.409 \mathrm{a}$ & $9.88 \mathrm{~d}$ & $6.43 \mathrm{I}$ \\
\hline $9-541 / \mathrm{D} / 9$ & $1.262 \mathrm{a}$ & $114.2 \mathrm{~b}$ & $73.58 \mathrm{e}$ & $0.319 \mathrm{e}$ & $4.770 \mathrm{de}$ & $9.78 \mathrm{e}$ & $6.85 \mathrm{f}$ \\
\hline $10-402 / 3 / 3 / 5$ & $0.836 \mathrm{~g}$ & 88.2 i & $67.00 \mathrm{~g}$ & $0.312 \mathrm{e}$ & $4.426 \mathrm{f}$ & $9.69 \mathrm{f}$ & $7.22 \mathrm{~b}$ \\
\hline Mean & 0.998 & 101.819 & 76.087 & 0.311 & 4.780 & 9.033 & 7.274 \\
\hline
\end{tabular}

Genotype means fallowed by the same letter (s) in a column are not significant by different at 0.05 levels of probability. 
Table 5. Means ( $\overline{\mathrm{x}})$ and calculated stability parameters $\left(\mathrm{b}_{\mathrm{i}}, \mathrm{S}^{2} \mathrm{~d}_{\mathrm{i}}, \mathrm{r}^{2}\right.$ and $\left.\mathrm{w}_{\mathrm{i}}\right)$ for straw, seed, fiber and oil yields per fad. and some technological characters over six environments.

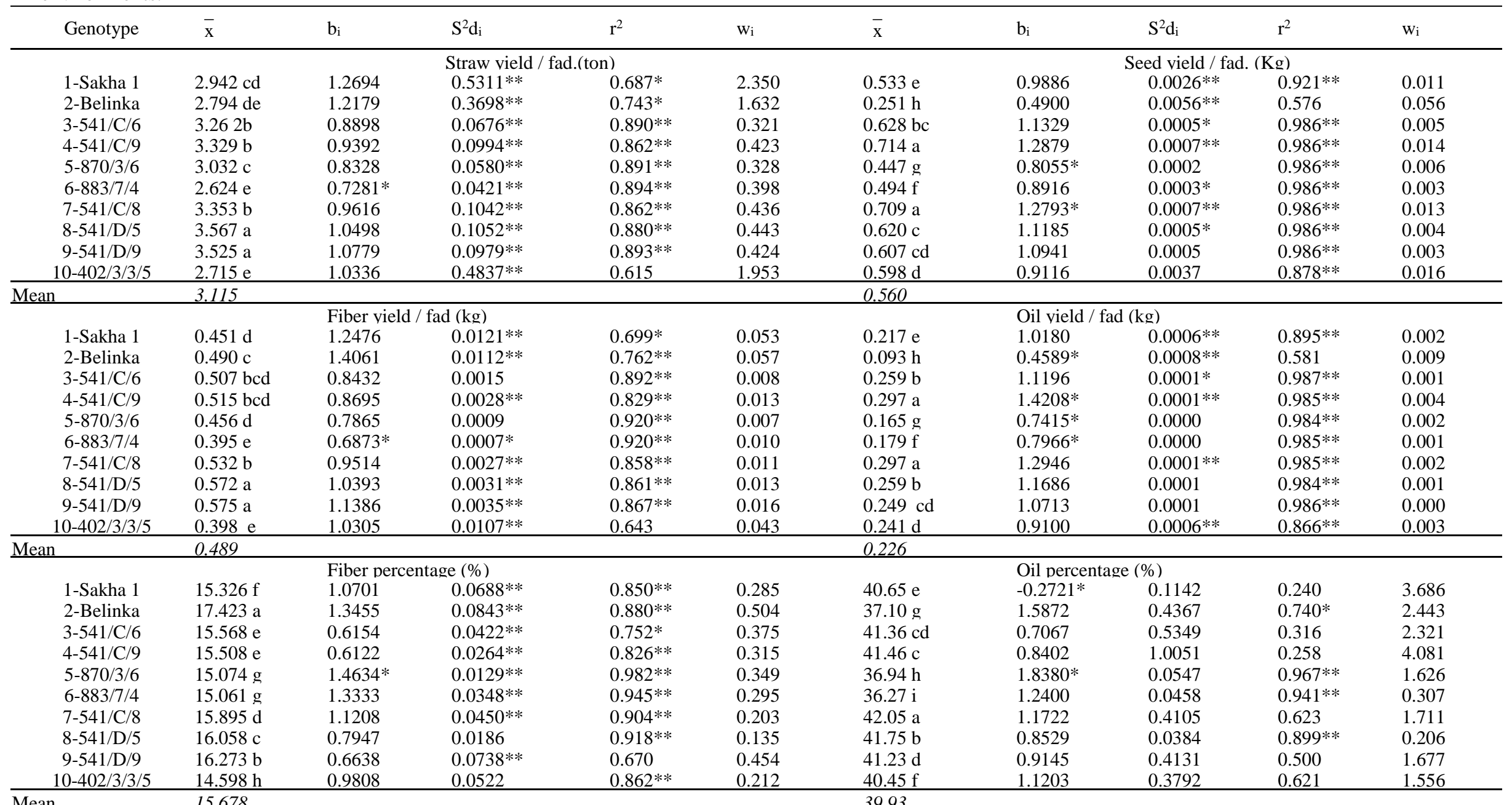

Genotype means fallowed by the same letter (s) in a column are not significant by different at 0.05 level of probability.

*,**: indicates deviation from regression is significantly different at 0.05 and 0.01 levels of probability. 
According to Bresse (1969) genotypes with regression coefficient greater than 1.0 would be adopted to more favorable environments, while those with coefficients less than one would relatively better adopted to less favorable conditions. According to Pinthus (1973) the ideal genotype had the high values of the coefficient of determination $\left(\mathrm{r}^{2}\right)$, and the low contribution of genotypes to GE sum of squares (w) according to Wricke (1962).

Out of the ten studied genotypes only two genotypes (L.541-D/5 and L.541-D/9) recoded high mean performance as well as exhibited good stability (general stability) according the four parameters of stability $\left(b_{i}, S^{2} d_{i}, r^{2}\right.$ and $\left.w_{i}\right)$ for both straw yield/fed and fiber yield/fed. Moreover, for fiber percentage, Belinka, L.541-D/9 and L.541-D/5 exhibited high degree of stability and mean values. Concerning seed yield/fed, four genotypes (L.541-C/9, L.541-C/8, L.541-D/5 and L.541-D/9) recoded high mean values and showed good stability. A simultaneous consideration of the four stability parameters evidenced that the most stable genotype was L.541C/8 followed by L.541-D/5 for both of oil yield/fed and oil percentage. Finally, L.541-D/5 could be considered as ideal genotypes for all six characters studied (Table 5) as well as L.541-C/8 could be considered as ideal genotypes for the three traits of seed (seed yield/fed, oil yield/fed and oil percentage). The previous collected data support the evidence that, the two promising lines, L.541-D/5 and L.541-C/8 may be considered as good (high yielding and stability) substitutes for the low yielding ones Sakha 1 (commercial variety) in future as a new Egyptian flax cultivars for straw, fiber, seed and oil yields (dual purpose type).

\section{Correlation studies:}

Phenotypic correlation coefficients among straw, seed weight/plant and their components of ten flax genotypes based on data of six environments (3 years x 2 locations) are present in Table (6). Straw weight had significant positive correlation with each of plant height, seed weight/plant, no. of capsules/plant and 1000-seed weight, indicating possibility of selecting genotypes that are characterized by high straw yielding ability and in the same time high seed yield potentialities. Moreover, the significant association between the two components, plant height and technical stem length are present. These results are in agreement with those obtained by Momtaz et al. (1977), Abo-El-Zahab et al. (1994) and Abo-kaied et al. (2008). However, seed weight/plant was significant positively correlated with both no. of capsules/plant and 1000-seed weight. Also, no. of capsules/plant exhibited significant positive correlation with 1000 -seed weight, indicating that both no. of capsules/plant and 1000-seed weight are the main components of seed weight/plant. These results are in a harmony with those reported by Momtaz et al. (1977); Abo-El-Zahab et al. (1994) and Abo-kaied et al. (2006). In contrast, no. of seeds/capsule exhibited significant negative correlation with each of straw weight, seed weight, no. of capsules/plant and 1000-seed weight. These results are in agreement with those obtained by Momtaz et al. (1977) and Abo-kaied et al. (2006). Abo-kaied et al. (2008)

Table 6. Phenotypic correlation coefficients among straw, seed weight per plant and their components of ten flax genotypes based on data of six environments.

\begin{tabular}{lllllll}
\hline Characters & $\mathbf{1}$ & 2 & $\mathbf{3}$ & 4 & $\mathbf{5}$ & 6 \\
\hline 1-Straw weight/plant $(\mathbf{g})$ & & & & & \\
\hline 2-plant height $(\mathbf{c m})$ & $0.865^{* *}$ & & & & & \\
\hline 3-Technical stem length $\mathbf{( c m )}$ & 0.435 & $0.765^{* *}$ & & & & \\
\hline 4-Seed weight/plant $(\mathbf{g})$ & $0.785^{* *}$ & 0.587 & 0.365 & & & \\
\hline 5-No. of Capsules/plant & $0.767^{* *}$ & $0.632^{*}$ & 0.477 & $0.941^{* *}$ & & \\
\hline 6-1000-seed weight $(\mathbf{g})$ & $0.703^{*}$ & 0.472 & 0.160 & $0.856^{* *}$ & $0.637^{*}$ & $-0.949^{* *}$ \\
\hline 7-No. of seeds/capsule & $-0.832^{* *}$ & -0.607 & -0.280 & $-0.956^{* *}$ & $-0.829^{* *}$ & - \\
\hline
\end{tabular}

$*, * *=$ Indicate significance at the 0.05 and 0.01 levels of probability, respectively.

\section{References}

A.O.A.C. (1995). Official Methods of Analysis. $16^{\text {th }}$ ed. Association of Official Analytical Chemist's. Washington, D.C., U.S.A.

Abo El-Zahab, A.A.; Mourad, N.K. and AboKaied, H.M.H. (1994). Genotype - environment interaction and evaluation of flax genotypes. 1 straw yield. Proc. $6^{\text {th }}$ Conf Agron., Al-Azhar Univ., Egypt, 1: 129-152.
Abo El-Zahab, A.A. and Abo-Kaied, H.M.H. (2000). Stability analysis and breeding potentialities of some stable selected flax genotypes. I . Breeding potentialities of straw yield and its contributing variables.Proc. $9^{\text {th }}$ conf.Agron.Minufiya Univ.2-3 Sept. 387-402.

Abo-Kaied, H.M.H; Abd El-Dayem, M.A. and Zahana, Afaf E. A. (2006). Variability and covariability of some agronomic and technological flax characters. Egypt J. Agric Res. 84: 1117-32. 
Abo-Kaied H.M.H.; Abuo Zaid, T.A. and Zahana, Afaf E. A. (2008). Evaluation of some flax genotypes for yield and yield components under different environmental conditions. Egypt. J. Agric. Res., 86(2): 597-610.

Abo-Kaied, H.M.H.; Abd El-Haleem, R. A.; ElKady, E.A.F.; El-Kady, Eman, A.A.; El-Refaie, Amany, M.M.; El-Deeb, E.I.; Mourad, N.K.M; Maysa, S. Abd Al-Sadek; El- Gazzar, A.M.A.; El-Sweify, Amna, H.; El-Shimy, G.H.; Kineber, M.E.A.; Afaf, E. A. Zahana; Mostafa, S.H.A.; Lotfy, E. E.; Hella, A.M.; Zedan, S.Z.; Sabah M. Abo El-Komsan; Omar, T.A.; Mousa, A.M.; El-borhamy, Amal, M.A.; Hussein, M..M.; Sanai, S. Hassan; El-Azzouni, E.E.; and Moawed, A.E.. (2015). Giza 11 and Giza 12; two new flax dual purpose type varieties. Arab Univ. J. Agric. Sci. Ain Shams Univ., Cairo, 23 (2), 525535.

Al-Jibouri, H.A. ; Miller, P.A. and Robinson, H.F. (1958). Genotypic and environmental variances and covariances in an upland cotton cross of interspecific origin.Agron.J.50: 633-636.

Bachireddy, V.R.; Payne, R.; Chin, Jr. K.L. and Kang, M.S. (1992). Conventional selection versus methods that use genotype $\mathrm{x}$ environment interaction in sweet corn trials. Hortscience 27: 436-438.

Bresse, E.L. (1969). The measurement and significance of genotype- environment interactions in grasses. Heredity, 24: 27-44.
Comstock, R.E. and Moll, R.H. (1963). Genotype environment interaction. P. 164-196. In Symp. on Statistical genetics and plant Breed., NAS-NRC. Pnb. 932. (C.F. Casler and Hovin, 1984, Crop Sci. 24: 633-636.

Eberhart, S.A. and Russell, W.A. (1966). Stability parameters for comparing varieties. Crop Sci. 6: 36-40.

Johnson, H.W.; Robinson, H.F. and Comstock, R.E. (1959). Estimates of genetic and environmental variability in soybeans. Agron.J.47: 314-318.

Kofoid, K.D.; Ross, W.M. and Mumm, R.F. (1978) Yield stability of sorghum random mating populations. Crop Sci. 18:677-679.

Momtaz, A.; Selim, A.K.A. and El-Shimy, G.H. (1977). Association studies between flax seed yield and some other characters. Agric. Res. Rev., 55: 45-55.

Mourad, N.K.M.; Mostafa, S.H.A. and Zahana, Afaf E.A. (2003). Yield, yield components, quality and variability assessment of some flax genotypes. Egypt J. plant Breed. 7: 129 -142.

Pinthus (1973). Estimate of genotypic value: A proposed Method. Euphytica 22: 121-123.

Wricke (1962). Uber eine Method Zur Eefassungder Okolgischen Streubreite in Feduersuchen. Z. F Pflanzenuchtug 47: 92-96. (C.F. Jowett, Crop Sci. 12: 314-17). 


\title{
التفاعل بين التركيب الوراثي والبيئة وتحليل الثبات للمحصول ومكوناته لعشرة تراكيب وراثية من الكتان
}

\author{
رمضان أحمد عبد الحليم - مايسة سعيد عبد الصادق - حسين مصطفي حسين أبوقايد \\ قسم بحوث محاصيل الألياف- معهد المحاصيل الحقلية-مركز البحوث الزراعية-الجيزة- مصر
}

تهدف الدراسـة الي دراسـة التفاعل بين التركيب الوراثي والبيئة وتحليل الثبات لعشـرة تراكيب وراثية من الكتان، اسـتخدم في هذه الدراسـة 10 تراكيب وراثية من الكتان تم تقيمها في 6 بيئات \}خلال ثلاثة سنوات (2013 / 2014 ، 2014 / 2015 ، 2015 / 2016) وموقعين (بالاسماعلية

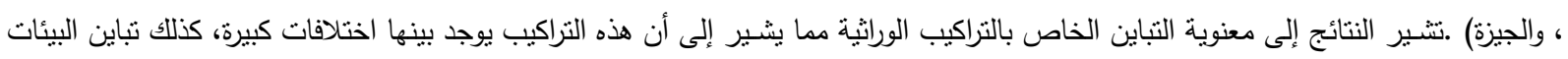

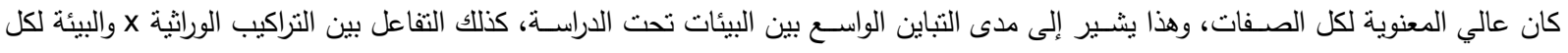

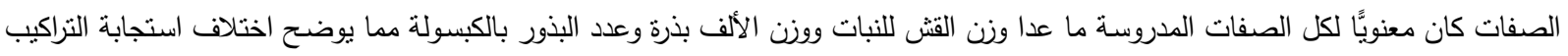

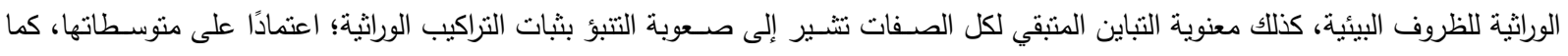

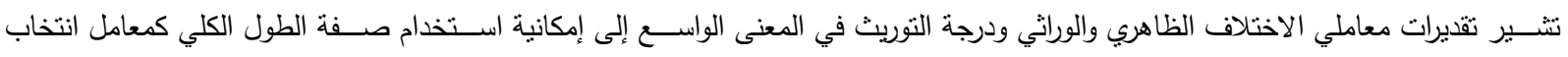
لتحسين وزن القش للنبات ، واستخدام كلٍ من وزن الألف بذرة وعدد الكبسولات للنبات كعوامل انتخابية لتحسين وزن البذور للنبات.

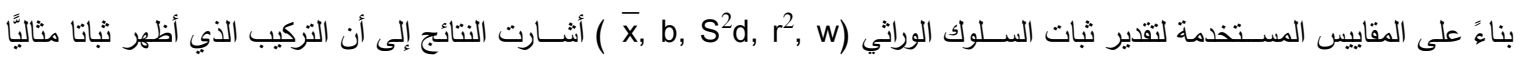

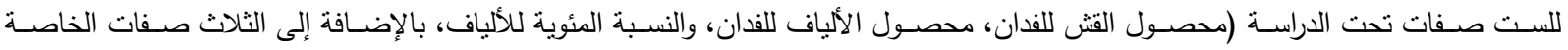

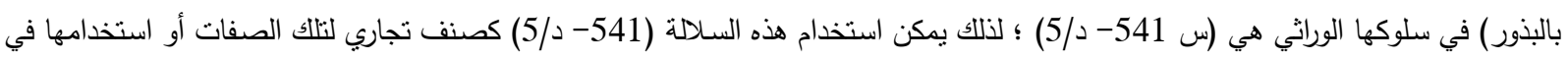

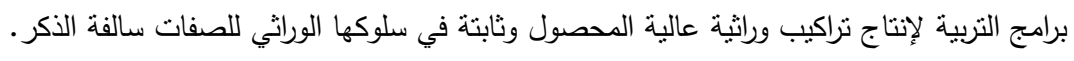

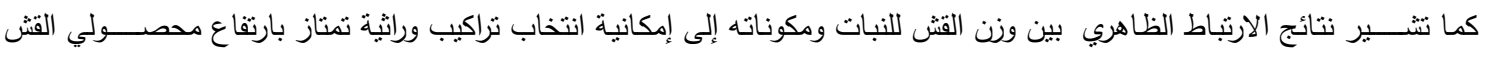
والبذور في نفس الوقت ـ كذللك كان هنالك ارتباط موجب ومعنوي بين وزن البذور للنبات وكلٍ من عدد الكبســـلات ووزن الألف بذرة، وكان هنالك أيضًا ارتباط موجب بين هاتين الصفتين؛ وبذلك يمكن استخدام الطول الكلي كعامل انتخابي لتحسين وزن القش للنبات، وكذلك يمكن استخدام (عدد التبن الكبسولات ووزن الألف بذرة) كعوامل انتخابية لتحسين وزن البذور للنبات. 